\title{
Research on the Analysis of the Cost of Logistics Enterprises_-Analysis Based on the Financial Statements of 15 Logisitics Listing Enterprises \\ Yongming $\operatorname{Pan}^{1, a}$, Ziwei Li ${ }^{1, b}$ \\ ${ }^{1}$ School of Management,Tianjin University of Technology,Tianjin,China \\ apym_tj@sina.com, b394927879@qq.com
}

Keywords: Logistics enterpris, Financial statement, Operating cost, Period charge

\begin{abstract}
With the development of domestic economy and the change of consumption patterns, especially the boom in online shopping, the logistics industry has a dramatic development in our country. Nevertheless, the logistics enterprises are still facing some issues such as high service cost, lack of competition, etc. Previous study on the cost of logistics enterprises concentrated more on the theoretical analysis. This study is based on the study of the logistics costs ratio using and contrast analysis to analyze the cost of main operation, period charge and main business income and according to the financial statement of 15 logistics listing enterprises,discuss the reasons of the high cost of logistics enterprises.
\end{abstract}

\section{Current situation of logistics cost}

In 2012, our country's logistics costs as a share of GDP at $17.8 \%$. In 2013, it did not decline, is still around 18\%, essentially flat with 2012. While at the same time, the developed countries, such as America, Japan, Germany, the total social logistics costs accounted for the proportion of the national GDP is respectively $8.5 \%, 8.7 \%$ and $8.3 \%$. The BRIC countries, such as India and Brazil, were respectively $13 \%$ and $11 \%$. The world average level is at $11.2 \%$. Therefore, the development and the operation efficiency of China's logistics industry is far behind the developed countries and the other BRIC countries, even behind the average level of the world.

Table1 the comparison of China's logistics cost data in 2012 and 2013 Unit: trillion RMB

\begin{tabular}{llll}
\hline Project & 2012 & 2013 & Growth rate \\
\hline The total cost of logistics & 9.4 & 10.2 & $8.5 \%$ \\
Transport cost & 4.9 & 5.4 & $10.2 \%$ \\
Administration cost & 1.2 & 1.3 & $8.3 \%$ \\
Storage cost & 3.3 & 3.6 & $9.1 \%$ \\
\hline
\end{tabular}

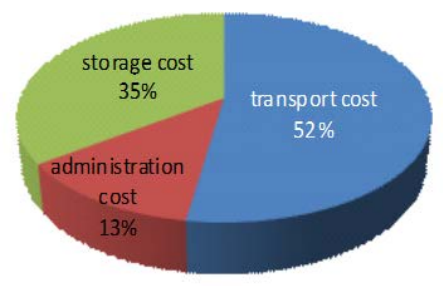

Fig. 1 The proportion of the total costs of logistics of 2013

From Table1 and Figure1 can be seen, in 2013, the total cost of the national social logistics reached 10.2 trillion RMB, increased by $8.5 \%$ compared with 2012. Among them, the transport cost ,administration cost and storage cost is respectively 5.4 trillion RMB, 1.3 trillion RMB and 3.3 
trillion RMB, accounting for the proportion of total logistics cost is respectively $52 \%, 13 \%$ and $35 \%$, year-on-year growth is respectively $10.2 \%, 8.3 \%$ and $9.1 \%[1]$.

In 2013, China's GDP growth rate is only $7.7 \%$, total logistics cost of society and the growth rate of transportation cost, management cost and storage costs have exceeded the growth rate of GDP, the logistics cost in China is visible has been in a high operational trend. The above data reflects the actual situation of China's logistics costs is at a high level from the macro.

\section{Analysis of financial statements of listed companies}

The logistics industry in China market is the mainstay of many small and medium enterprises. Because of the limitations of objective conditions, the relevant data of these enterprises are difficult to obtain. In contrast, logistics listing corporation as the point to China's logistics industry development level, its financial statements through strict audit and published regularly can guarantee the authenticity, accuracy of the data[2].

At present, the cost of logistics enterprises is usually divided into two categories, operation cost and period expense.

But the cost of logistics enterprises is particular, compared with the manufacturing enterprise, the product or service is invisibility, the production and sales even the consumption of the product or service is an organic unity.

We only use the traditional manufacturing enterprise cost accounting system Therefore, the cost of logistics enterprises form can be represented in figure 2 (due to the logistics enterprises productive activity is less, it is the operating costs instead of manufacturing expenses in the enterprise accounting system).

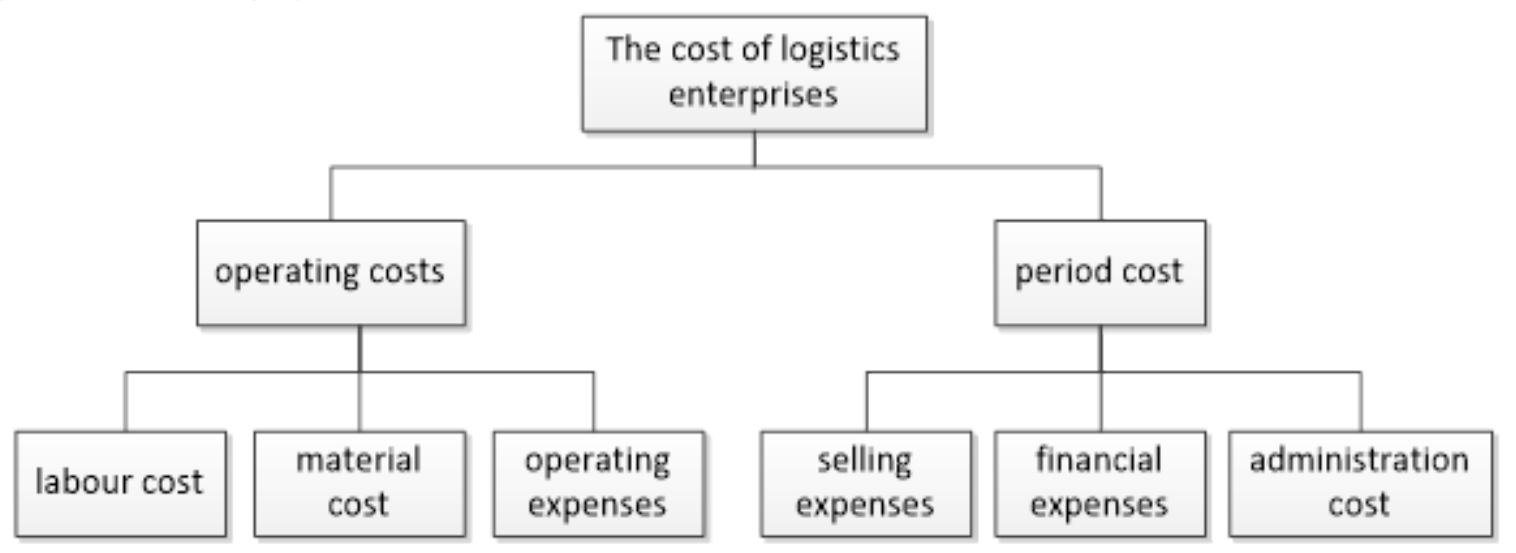

Figure 2 The constitution of the cost of logistics enterprises

According to industry classification standard, the logistics industry should be made up of transportation, warehousing and postal service, specifically including rail transport, water transport, road transport, air transport, pipeline transport, shipping agency, warehousing, postal service and handling, etc. This article selects 15 enterprises of all kinds of main business logistics company appear on the stock markets of Shanghai and Shenzhen as sample (the required data of the 15 listed company's financial statements are provided by the Juchao net).

Analysis of operation cost. Logistics enterprises operating cost refers to the actual occurrence of logistics enterprises in the process of production related to transportion, loading and unloading, handling, storage, packaging, circulation processing business and other business directly or indirectly. According to the morphogenesis it divided into direct materials, direct labor and operating costs[3]. Analysis the main business cost and main business income in the profit table.The result is shown in table 2. 
Table 2 The income and cost data of 15 listed logistics company in 2013Unit: RMB

\begin{tabular}{|c|c|c|c|}
\hline The main business & Business income & Operating cost & Cost revenue percentage \\
\hline \multicolumn{4}{|l|}{ Railway transportation : } \\
\hline China Railway Tielong & $4,280,599,730.87$ & 3,613,720,166.41 & $84.42 \%$ \\
\hline Daqin Railway & $51,342,739,663$ & $32,306,787,587$ & $62.92 \%$ \\
\hline \multicolumn{4}{|l|}{ Handling and transportation agent: } \\
\hline CTS Global Logistics & $8,533,354,432.84$ & $8,065,936,602.75$ & $94.52 \%$ \\
\hline Aucksun & $1,466,637,434.85$ & $1,214,345,837.51$ & $82.80 \%$ \\
\hline \multicolumn{4}{|l|}{ Storage : } \\
\hline Xinning Logistics & 368,341,989.31 & $252,085,279.80$ & $68.44 \%$ \\
\hline Feiliks & 2,366,422,117.41 & $1,970,197,825.34$ & $83.26 \%$ \\
\hline Huapengfei & $405,034,933.51$ & $309,712,530.21$ & $76.47 \%$ \\
\hline \multicolumn{4}{|l|}{ Water transport: } \\
\hline COSCO & $6,947,200,168.77$ & 6,684,641,381.92 & $96.22 \%$ \\
\hline Zhongchang Marine & $427,619,658.52$ & $388,945,101.09$ & $90.96 \%$ \\
\hline China Shipping Development & $11,348,599,054.88$ & $11,239,439,433.24$ & $99.04 \%$ \\
\hline \multicolumn{4}{|l|}{ Road transport: } \\
\hline YTP & $307,695,495.77$ & $126,400,704.62$ & $41.08 \%$ \\
\hline Xiandai Investment Company & $1,576,970,748.14$ & $620,353,232.35$ & $39.34 \%$ \\
\hline Dongguan holdings & $744,397,612.61$ & $267,496,094.66$ & $35.93 \%$ \\
\hline \multicolumn{4}{|l|}{ Air transport: } \\
\hline $\mathrm{COHC}$ & 1,187,193,388.15 & $877,330,210.66$ & $73.90 \%$ \\
\hline Shenzhen airport & 2,459,333,261.23 & $1,662,213,775.59$ & $67.59 \%$ \\
\hline
\end{tabular}

As can be seen from table 2, in 15 enterprises, water transport as the main business enterprises have the highest cost of the proportion of income, among which, China shipping development cost and its main business income is considerably, indicating that the enterprise's profitability is poor. the handling and transportation agent logistics enterprise, Aucksun and CTS Global Logistics, is also at a relatively high level, the cost to income ratio is more than $80 \%$. Two Rail based transport enterprises--- China Railway Tielong and Daqin Railway, the proportion of income is much more different, respectively $84.42 \%$ and $62.92 \%$. Mainly based on air transport, COHC and Shenzhen airport's cost to income ratio is between the $65 \%$ and $75 \%$, at the middle level. Three storage enterprises cost to income ratio is in the middle level, respectively $68.44 \%, 83.26 \%, 76.47 \%$. The lowest is in road transport oriented enterprises, the representative of it,Yantian port, Dongguan holdings, cost to income ratio is at around $40 \%$ or less. Thus, in most of the logistics enterprises, the cost of main business accounted for a considerable proportion, its profitability is poor.It can be seen from the above analysis, although the logistics industry has developed rapidly in our country, the logistics enterprise's profit situation is not ideal, the enterprise cost control ability is poor, the operation efficiency is low.

Analysis of period cost, Period costs of enterprises is an important part of the costs incurred in the current, refers to all expenses occurring in the period, can not directly or indirectly into some kind of product costs and directly included in the profit and loss, including selling cost, administration cost and financial cost. Analysis the selling cost, administration cost and financial cost income in the profit table. The result is shown in table 3. 
Table 3 The period cost data of 15 listed logistics company in 2013Unit: RMB

\begin{tabular}{|c|c|c|c|c|c|c|c|}
\hline company & selling cost & administration cost & \multicolumn{2}{|l|}{$\begin{array}{l}\text { financial } \\
\text { cost }\end{array}$} & $\begin{array}{l}\text { Admi } \\
\text { /income }\end{array}$ & $\begin{array}{l}\text { Financial/ } \\
\text { income }\end{array}$ & \multirow[t]{2}{*}{$\begin{array}{l}\text { Total/ } \\
\text { income }\end{array}$} \\
\hline \multicolumn{7}{|c|}{ Railway transportation : } & \\
\hline Tielong & $24,543,221.37$ & $72,660,722.87$ & $6,324,909.03$ & $0.57 \%$ & $1.70 \%$ & $0.15 \%$ & $2.42 \%$ \\
\hline Daqin & $188,873,682$ & $3,152,158,506$ & $663,925,381$ & $0.37 \%$ & $6.14 \%$ & $1.29 \%$ & $7.80 \%$ \\
\hline \multicolumn{8}{|c|}{ Handling and transportation agent: } \\
\hline CTS & $222,548,632.72$ & $113,440,961.60$ & $17,455,239.87$ & $2.61 \%$ & $1.33 \%$ & $0.20 \%$ & $4.14 \%$ \\
\hline Aucksun & $27,555,363.82$ & $36,397,159.95$ & 26,032,368.96 & $1.84 \%$ & $2.43 \%$ & $1.74 \%$ & $6.02 \%$ \\
\hline \multicolumn{8}{|l|}{ Storage : } \\
\hline Xinning & $16,421,567.01$ & $80,264,173.65$ & $7,278,938.65$ & $4.46 \%$ & $21.79 \%$ & $1.98 \%$ & $28.23 \%$ \\
\hline Feiliks & $46,629,276.64$ & $243,998,900.44$ & $8,836,760.91$ & $1.97 \%$ & $10.31 \%$ & $0.37 \%$ & $12.65 \%$ \\
\hline Huapengfei & $19,030,597.52$ & $28,500,294.44$ & 8,364,355.03 & $4.70 \%$ & $7.04 \%$ & $2.07 \%$ & $13.80 \%$ \\
\hline \multicolumn{8}{|c|}{ Water transport: } \\
\hline COSCO & $48,088,591.40$ & $352,859,689.81$ & $204,223,680.17$ & $0.65 \%$ & $4.74 \%$ & $2.74 \%$ & $8.13 \%$ \\
\hline Zhongchang & - & $31,515,751.98$ & $117,522,956.13$ & - & $7.33 \%$ & $27.32 \%$ & $34.65 \%$ \\
\hline CSD & 49,309,161.73 & $464,744,229.73$ & $1,050,872,679.04$ & $0.43 \%$ & $4.08 \%$ & $9.22 \%$ & $13.74 \%$ \\
\hline \multicolumn{8}{|l|}{ Road transport: } \\
\hline YTP & - & $49,110,325.82$ & $-12,141,378.00$ & - & $15.96 \%$ & $-3.95 \%$ & $12.01 \%$ \\
\hline Xiandai & $7,118,228.31$ & $205,806,348.51$ & $105,137,857.94$ & $0.41 \%$ & $11.73 \%$ & $5.99 \%$ & $18.13 \%$ \\
\hline Dongguan & - & 41,332,283.52 & $60,345,209.29$ & - & $5.40 \%$ & $7.89 \%$ & $13.30 \%$ \\
\hline \multicolumn{8}{|l|}{ Air transport:: } \\
\hline $\mathrm{COHC}$ & - & $1,162,254.74$ & $4,918,416.85$ & - & $0.12 \%$ & $0.51 \%$ & $0.64 \%$ \\
\hline Shenzhen & $4,754,489.83$ & $83,945,400.13$ & $5,714,663.21$ & $0.26 \%$ & $4.64 \%$ & $0.32 \%$ & $5.22 \%$ \\
\hline
\end{tabular}

As can be seen from table 3, 15 selected listed companies in this paper, only Xinning logistics and Zhongchang Marine, the period cost of which cost for a higher proportion, more than 25\%; With four logistics companies operating costs accounted for the proportion of revenue at about $13 \%$; The period cost of income of the rest of the enterprise are below 10\%. The period cost of income of $\mathrm{COHC}$ is only $0.64 \%$.This shows that the majority of enterprises operation and management of funds are in a good state, with high efficiency.

But the costs in three during the majority of enterprises, administration cost account for the highest proportion. This indicates that China's logistics enterprise management level is not very advanced. There is space and potential to improve.

In the rest of the firms, financial costs accounted for a larger proportion. The financial cost of income of Zhongchang Marine reached 27.32\%, which reflects the reality of the situation that financing cost is high to enterprise in our country current.

In addition, the data in the table reflects the fact that in the 15 companies, there are 4 companies without the accounting of selling cost, focus on transport as the main business of enterprises, and the selling cost of the rest transport enterprise are below 1\%. That is because in the traditional manufacturing, selling cost include marketing costs, distribution costs, and for the logistics enterprises, the distribution cost of itself should be classified as operating cost rather than period cost. This further illustrates the organic unity of production, sales logistics enterprises and even consumption. The reason of high cost of logistics enterprises

Rising labor costs, Both the production or service activities and the enterprise management activity of the enterprise cannot do without the participation of employees. At present, due to 
changes in labor supply and demand and life service costs rise in China, making labor resource advantage is gradually disappear, with abundant cheap labor times gone forever. And the price of labor continues to improve, directly increase the labor cost of logistics enterprises. In the case of the current logistics enterprises are highly dependent on manual work, the cost of logistics enterprise rises sharply has become inevitable.

Rising materials cost, Logistics industry is closely related to oil, fuel consumption is large, whether it is shipping, air transport or road transport, all cannot do without fuel. Now the oil price increases and amplitude are far more than cut frequency and amplitude, it has greatly increased the logistics enterprises of the cost of raw materials. Now the times and amplitude of oil prices increase is far more than the down, which will undoubtedly greatly improve the logistics enterprise's raw material cost. In addition, current prices rising in China, such as packaging and other materials prices also further rising cost of logistics enterprises.

The high cost of operation, Due to the invisibility of logistics product and service, the cost of logistics enterprises reflects almost no goods entity transfer. The main consumption is the operating cost and the cost of direct material consumption is relatively small, which makes the current logistics enterprises has the characteristics that the operating costs is at a high proportion.

Toll expressway projects often reported in the report and a multitude of names of various fines also increased logistics enterprises additional operating costs in our country.

Administration costs are relatively high, High administration cost shows that the current management level of logistics enterprises in our country is still at a low level. Because the great one-time investment cost, many enterprises still relies mostly on manual operation rather than the advanced automatic control system in the practice.But in fact, the proper use of the automatic control system can effectively reduce the unloading、 handling cost and labor management costs, thereby reducing the administration cost.

Poor infrastructure and low operating efficiency, From the view of geographical distribution, the railway network and the field distribution in China are more concentrated in the eastern region. the port is also concentrated in the southeast coastal areas. The infrastructure in the central and western regions are relatively backward. In addition, the energy resources is distributed mainly over the West and North, but the manufacturing industry was concentrated in the East and Southeast coastal. The actual situation of production layout in China requires materials can be circulated nationwide, but poor infrastructure increase the difficulty to develop nationwide logistics service by logistics enterprises[4].

Cost accounting is not accurate, There is not a set of specialized logistics cost accounting system to manage the cost of logistics enterprises[5]. Simply actual cost will be included in the main business cost. The logistics enterprises are based on their own situation and different accounting methods of enterprise to account and control the internal logistics cost of enterprise. This reduce comparability of cost accounting results between the logistics enterprises ,so the level of management cannot be compared. The cost of logistics enterprises cannot be reasonably and effectively control.

\section{References}

[1] S.H. Sun. China logistics costs GDP accounted for more than two times than developed countries, the multi sector brewing new deal. Ecnomic Information.http://news.hexun.com/2013-11-27/160051367.html,2013-11-27.

[2] S.A. Hou and S. Wan. VAT " Spread around " and the development of service outsourcing industry - based on financial statement analysis of 13 service outsourcing listed companies in China. Taxation Research,2013,01:60-63.

[3] J.R. Shen and X.D. Xiao. A Study on the Cost Control in Logistics Enterprise. Journal of Northen Jiaotong University,2001,05:83-85+90. 
[4] H.S. So. Comparative analysis and Enlightenment of logistics cost between China and America . Macroeconomic Management,2014,01:85-87.

[5] S.H. Liu. The Causes for the High Logistic Cost and the Countermeasures. China Business and Market,2012,07:38-42. 